\title{
APLIKASI PENGADUAN MASYARAKAT TERHADAP INFRASTRUKTUR BERBASIS ANDROID PADA DESA SINDANGSARI
}

\author{
Teguh Sumarno $^{1}$, Ade Mubarok ${ }^{2}$ \\ Sistem Informasi, Universitas Adhirajasa Reswara Sanjaya ${ }^{1}$ \\ email: teguhtsumarno@gmail.com ${ }^{1}$ \\ Sistem Informasi, Universitas Adhirajasa Reswara Sanjaya ${ }^{2}$ \\ email: adem@ars.ac.id ${ }^{2}$
}

\begin{abstract}
Abstrak
Pengaduan saat ini umumnya masih menggunakan tatap muka sehingga masyarakat harus datang ke instansi tersebut untuk melakukan pengaduan. sedangkan masyarakat banyak yang tidak tau tentang birokrasi pemerintahan desa hal ini menjadi masalah terjadinya kesalahan pengaduan masyarakat yang tidak sesuai jalur birokrasinya, sehingga pengaduan masyarakat kurang ditanggapi oleh pihak desa. Karena itu penulis tertarik untuk memberikan sebuah solusi dari persoalan tersebut maka dibuatlah aplikasi pengaduan masyarakat. aplikasi pengaduan masyarakat dapat memudahkan masyarakat untuk melakukan pengaduan tanpa harus datang ke desa dan pengaduan dapat disampaikan sesuai jalur birokrasi desa. metode peneliti menggunakan metode SDLC (System Development Life Cycle) dalam melakukan perancangan aplikasi dengan model proses Waterfall. Dengan aplikasi pengaduan masyarakat, masyarakat dapat melakukan pengaduan dengan lebih mudah dan dapat dilakukan dimanapun tanpa ada batasan jam kerja, selain itu, kinerja petugas desa juga akan lebih cepat dan tepat untuk menanggapi pengaduan dari masyarakat.
\end{abstract}

Kata Kunci: Aplikasi, Waterfall, Pengaduan, Masyarakat

\begin{abstract}
Complaints currently still use face-to-face so the community should come to the institution to make a complaint. While many communities do not know about the village government bureaucracy, this is a problem of community complaints errors that are not according to the bureaucracy, so the village participates in responding to public complaints. Therefore the author is interested to provide a solution to the problem, then a community complaints application is made. The community complaints application can ease the community to command complaints without them having to come to the village and complaints can be submitted according to the village bureaucracy. researchers method using sdlc (system development life cycle) method in design applications with waterfall process model. With the community complaints application, the community can make complaints easier and can be done anywhere without limitations of working hours, in addition, the performance of village officers will also be faster and appropriate to respond to complaints.
\end{abstract}

Keywords: Application, Waterfall, Complaint, Community

\section{PENDAHULUAN}

Perkembangan teknologi informasi dan komunikasi yang semakin pesat menjadi bagian dari perkembangan zaman yang tidak terpisahkan dari masyarakat sampai saat ini, dimana sekarang peran teknologi telah memberikan tuntutan besar bagi pemerintah untuk bisa menyediakan pelayanan yang mudah dan cepat, sehingga masyarakat dapat dengan mudah mengetahui informasi yang dibagikan pemerintah, hal ini dapat menjadikan kesan masyarakat pada pemerintah menjadi lebih (Atthahara, 2018). Semakin berkembangnya teknologi informasi dan komunikasi saat ini, menjadikan teknologi informasi dan komunikasi semakin mudah untuk diakses dan di terapkan dalam berbagai bidang, seperti pendidikan, kesehatan, perdagangan dan pemerintahan. Hal ini tidak lepas dari banyaknya keunggulan yang dimilikinya, seperti cepatnya mengakses data dan biaya yang tergolong lebih murah dibandingkan dengan cara tradisional (Rio \& Rina, 2017). 
Pada sebuah instansi pengaduan masyarakat sangatlah dibutuhkan, agar dapat mengukur keberhasilan, kekurangan dari program instansi yang telah dijalankan, dan untuk menerima kritik dan saran dari masyarakat. kebanyakan pengaduan yang dilaporkan masyarakat adalah bidang sarana fasilitas dan pelayanan umum(Eriyani, 2019). Setiap fasilitas atau pelayanan publik yang digunakan masyarakat apabila tidak sesuai dengan apa yang masyarakat inginkan akan menimbulkan keluhan bagi masyarakat dan melakukan pengaduan ke instansi sebagai pernyataan ketidakpuasan masyarakat akan pelayanan yang diberikan instansi, baik secara lisan maupun tertulis (Mahdias et al., 2019).

Desa merupakan salah satu bagian dari pemerintahan yang berperan penting untuk kemajuan pembangunan dari sebuah daerah, dan desa juga adalah bagian pemerintahan yang paling sering berinteraksi langsung dengan masyarakat, terutama dalam hal menerima keluhan dan pengaduan dari masyarakat (Rozi et al., 2017). Banyaknya keluhan dan tuntutan dari masyarakat pada pemerintahan, menjadikan pemerintahan harus bisa menangani keluhan dan tuntutan dari masyarakat secara cepat dan tepat, agar terwujudnya pelayanan yang cepat dan tepat maka pemerintah harus mengutamakan sektor pelayanan publik agak data keluhan dari masyarakat dapat dikelola dengan baik (Mursalim, 2018). Pengaduan ataupun penyampaian aspirasi serta keluhan masyarakat merupakan perihal penting pada sebuah lembaga. Sebab dengan terdapatnya penyampaian aspirasi lembaga bisa dengan mudah memperbaiki, meningkatkan kualitas dan dapat mengetahui apa yang masyarakat butuhkan. (Naomi et al., 2019).

Desa Sindangsari saat ini masih menggunakan tatap muka untuk melakukan atau menyampaikan pengaduan dari masyarakat sehingga mengharuskan masyarakat untuk datang secara langsung ke kantor desa. Akan tetapi, terdapat kendala di dalamnya yaitu terbatasnya jam kerja dan ketidaktahuan masyarakat akan birokrasi desa untuk menyampaikan pengaduan, sehingga pemerintah desa tidak bisa melayani serta menampung semua pengaduan atau laporan yang disampaikan oleh masyarakat. Berdasarkan data yang diperoleh dari aparat desa setempat bahwasanya rata-rata pengaduan yang diterima oleh pihak desa 6 bulan terakhir sejumlah 15 laporan. Selain itu untuk penyampaian informasi desa Sindangsari masih menggunakan cara manual, dengan cara memberi informasi kepada kepala RT/RW dan juga melalui media papan pengumuman yang ada di kantor desa, hal ini menyebabkan penyampaian informasi yang disampaikan kepada masyarakat tidak bisa didapatkan secara cepat, lengkap dan menyeluruh karena jangkauan informasi yang sangat terbatas.

\subsection{Tinjauan Studi}

Menurut Naomi (2019) dengan judul "Analisa dan Perancangan Sistem Pengaduan Mahasiswa Berbasis Web (Studi Kasus: Universitas Mercu Buana Kranggan)", yang dimana Penelitian ini membahas tentang permasalahan yang ada pada Universitas Mercu Buana dalam mengajukan pengaduan kepada pihak kampus. Proses pengaduan yang berjalan saat ini masih menggunakan cara manual, mahasiswa harus datang ke kampus dan datang ke bagian humas untuk mengisi form pengaduan atau melalui SMS (Short Message Service). Proses pengumpulan data dalam perancangan ini menggunakan metode PIECES untuk menganalisa penilaian elemen analisis dna metode perancangan UML untuk membuat rancangan desain. Hasil penelitian ini berupa rancangan sistem berbasis web yang memudahkan mahasiswa untuk membuat pengaduan dan melihat sudah sejauh mana pengaduan diproses oleh pihak kampus.

Menurut Alviansyah (2018) dengan judul "Evaluasi Kegunaan pada Purwarupa Aplikasi Pelaporan Kerusakan Infrastruktur", yang dimana permasalahan yang ada pada penelitian ini adalah website LACAK (Lapor Cari Perbaiki) masih belum digunakan secara luas oleh masyarakat untuk melaporkan kerusakan infrastruktur akibat bencana. Metode yang digunakan oleh peneliti adalah metode analisis. Hasil penelitian ini adalah membuat LACAK mendapatkan tingkat SUS pada Skala Good dan dipergunakan secara luas oleh masyarakat.

Dari hasil penelitian-penelitian sebelumnya mengenai aplikasi pengaduan dengan penelitian ini memiliki beberapa perbedaan diantaranya, penelitian sebelumnya berbasis website sedangkan untuk penelitian ini sudah berbasis android, dan untuk metode yang digunakan pun berbeda. 


\section{METODE PENELITIAN}

Metode penelitian merupakan suatu cara untuk memecahkan masalah menggunakan teknik pengumpulan data dan model pengembangan sistem.

\subsection{Teknik Pengumpulan Data}

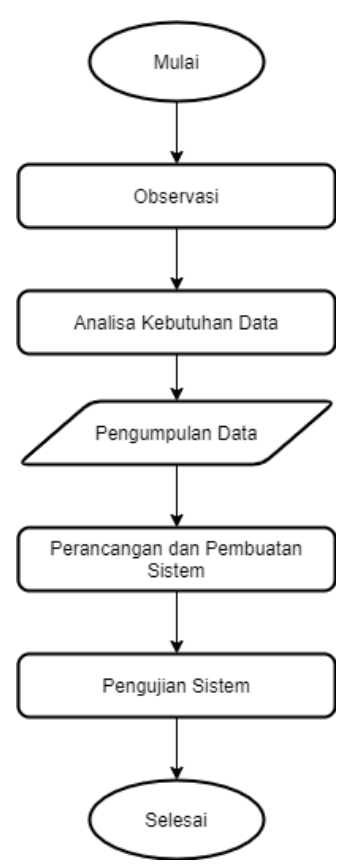

Gambar 1. Flowchart Teknik Pengumpulan Data

\section{Observasi}

Dilakukan pengamatan langsung pada desa Sindangsari dan mengamati prosedur dan sistem yang sedang berjalan untuk mendapatkan informasi yang bisa dijadikan sebagai data penelitian.

\section{Analisa Kebutuhan}

Dilakukan untuk memperoleh data, model, spesifikasi tentang perangkat lunak serta perangkat keras, yang akan digunakan sebelum membuat program aplikasi.

\section{Pengumpulan Data}

Pengumpulan Data berasal dari requirement yang sebelumnya sudah ditetapkan bersumber pada penggabungan informasi primer serta sekunder. Requirement adalah catatan kebutuhan serta persyaratan dari aplikasi, Dengan terdapatnya requirement, pembuatan aplikasi akan bisa terencana serta terstruktur. Tidak hanya itu, requirement pula bisa menolong dalam melaksanakan testing kala aplikasi sudah selesai dibuat.

4.Perancangan Dan Pembuatan Sistem

Sebelum sistem ataupun aplikasi terbuat, peneliti membuat rancangan dari aplikasi yang hendak dibuat. Dengan dibuatannya rancangan ini bertujuan untuk memudah peneliti dalam melakukan pengaplikasian pada sistem atau aplikasi yang hendak dibuat serta bisa sesuai dengan yang diharapkan serta tidak terdapat fitur yang kurang ataupun tertinggal

5.Pengujian Sistem

Sistem yang telah jadi akan diuji sesuai dengan requirement yang telah ditentukan sebelumnya. Seluruh requirement harus terpenuhi dan tidak ada yang tertinggal ataupun tidak sesuai dengan requirement. Pengujian sistem sendiri akan dicoba dengan memakai tata cara black box testing.

2.2 Metode Pengembangan

Penelitian ini menggunakan metode pengembangan sistem Software Development Life Cycle (SDLC) model waterfall. 


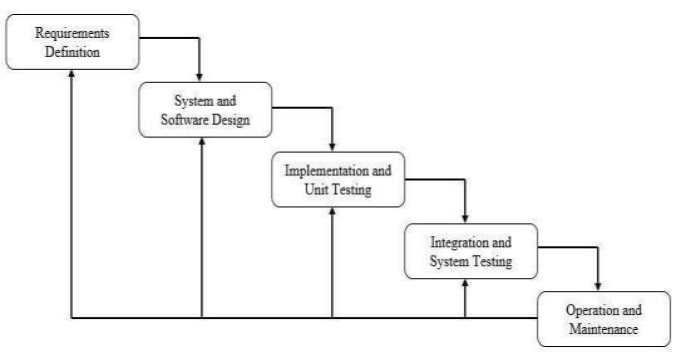

Gambar 2. Metode Waterfall

\section{Requirement Definition}

Pada tahap ini pengembang mesti dapat mengetahui dan memahami informasi serta keperluan dari pengguna terhadap aplikasi. informasi ini dapat diperoleh dengan cara diskusi, wawancara atau survei langsung. Informasi yang didapat kemudian akan diolah sehingga didapatkan data yang lengkap mengenai kebutuhan pengguna terhadap aplikasi yang akan dikembangkan.

2.System and Software Design

Spesifikasi kebutuhan dari tahap Requirement Definition akan dianalisa untuk kemudian diterapkan kepada desain. Perancangan desain sendiri dilakukan supaya dapat memperlihatkan gambaran lengkap pada pengembang menimpa apa yang mesti dikerjakan. pada bagian Requirement Definition akan membantu pengembang untuk mempersiapkan kebutuhan perangkat keras untuk pembuatan arsitektur sistem secara keseluruhan.

\section{Implementation and Unit Testing}

Pada tahap ini ialah tahap pengkodean. perancangan perangkat lunak dipecah menjadi sebagian modul-modul kecil yang akan digabungkan dalam tahapan selanjutnya, pada bagian ini dilakukan pengujian dan pengecekan pada setiap unit yang dikemabangkan dan diuji terhadap fungsionaliatsnya, apakah telah memenuhi kriteria yang diinginkan ataupun belum.

\section{Integration and System Testing}

Setelah semua unit atau modul yang dikembangkan serta diuji dalam sesi implementasi, berikutnya akan diintegrasikan dalam sistem secara menyeluruh, Setelah proses integrasi seluruh sistem diuji, kemudian dilakukan pengecekan dan pengujian sistem dengan menyeluruh untuk mengenali adanya kegagalan atau kesalahan dalam sistem yang dikembangkan.

\section{Operation and Maintenance}

Pada sesi terakhir ini, perangkat lunak yang telah selesai dioperasikan oleh pengguna dan dilakukan pemeliharaan. Pemeliharaan bertujuan untuk melakukan perbaikan terhadap kekeliruan yang tidak diketahui di tahapan sebelumnya. Proses pemeliharaan sendiri mencakup beberapa aspek seperti perbaikan implementasi unit sistem, perbaikan kesalahan, ataupun peningkatan serta penyesuaian sistem

\section{HASIL DAN PEMBAHASAN}

A. User Interface Android

1. Halaman Berita 


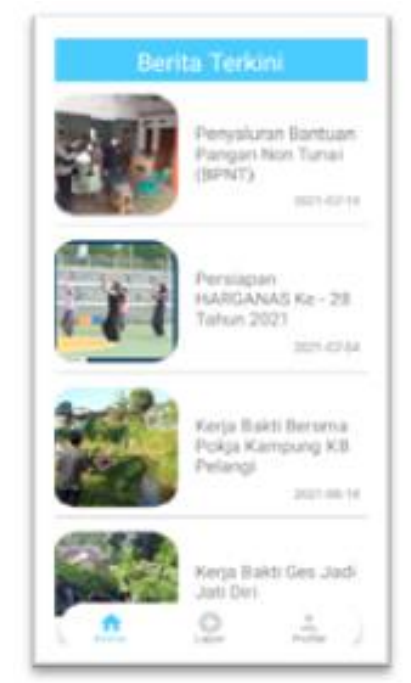

Gambar 3. Halaman Berita

Pada halaman home berisi list berita yang diupload oleh pihak desa, untuk setiap berita yang diupload berisikan, judul berita, tanggal dibuat berita dan gambar.

2. Halaman Pengaduan

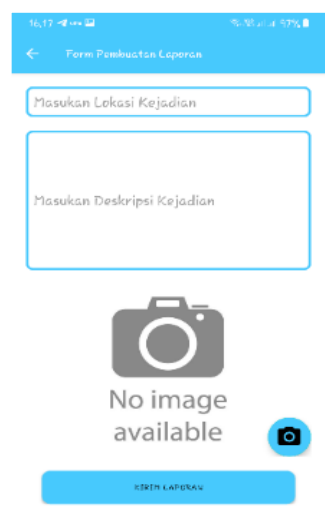

Gambar 4. Halaman Pengaduan

Halaman Pengaduan kegiatan terdiri dari tiga form yang wajib diisi yaitu memasukan lokasi kejadian, deskripsi kejadian, foto kejadian.

3. Halaman Profile 


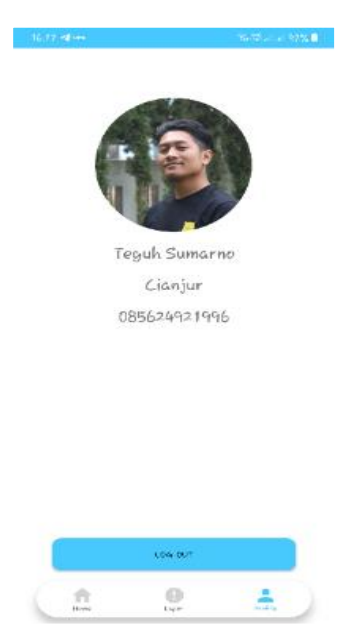

Gambar 5. Halaman Profile

Halaman profile menampilkan data dari pengguna seperti foto, nama, alamat, nomor handphone, dan memiliki satu buah tombol untuk logout.

\section{B. User Interface Website}

1. Halaman Home

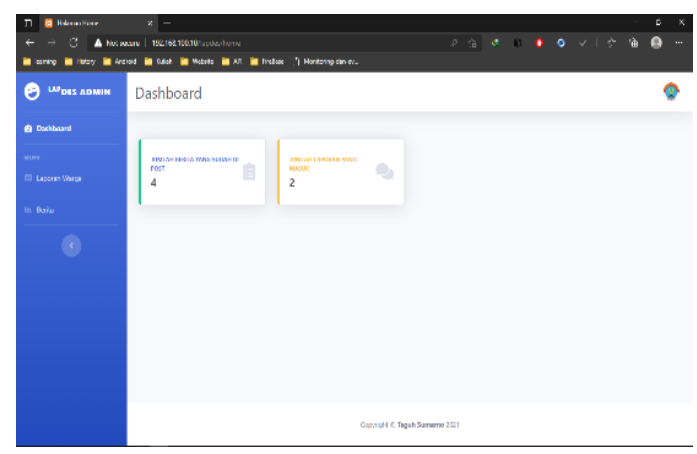

Gambar 6. Halaman Home

Merupakan halaman utama sesudah admin berhasil login pada halaman ini terdapat dua card view yang menunjukan jumlah berita yang sudah di post dan jumlah laporan yang masuk dari pengguna atau masyarakat.

2. Halaman Berita

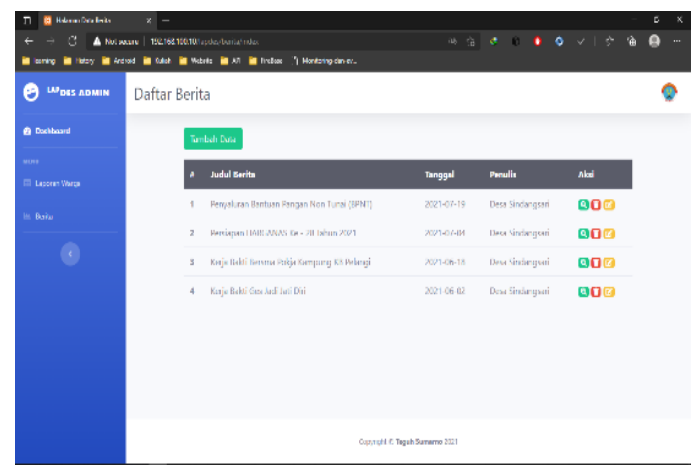

Gambar 7. Halaman Berita

Halaman daftar berita berisi list berita yang sudah di post, dan memiliki aksi seperti tambah berita, lihat detail, hapus dan edit.

3. Halaman Laporan 


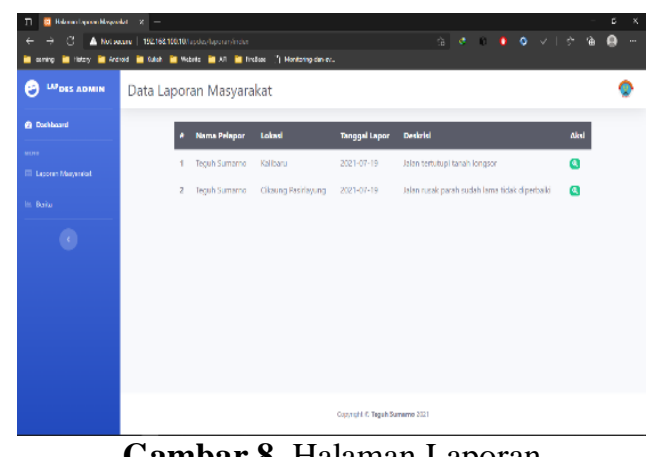

Gambar 8. Halaman Laporan

Halaman laporan masyarakat berisi list laporan dari masyarakat yang melakukan pengaduan lewat aplikasi, berikut merupakan tampilan dari halaman laporan masyarakat.

\section{KESIMPULAN DAN SARAN}

Dari hasil dan pembahasan yang telah dilakukan dalam aplikasi pengaduan masyarakat terhadap infrastruktur berbasis android pada desa sindangsari, maka diperoleh kesimpulan sebagai berikut, Aplikasi yang dibangun dapat menyalurkan aspirasi, keluhan dan pengaduan masyarakat yang dapat dilakukan dimana dan kapan saja dan Masyarakat dapat memperoleh informasi dari desa dengan cepat, jelas dan lengkap lewat fitur berita pada aplikasi.

Dan saran untuk pengembangan selanjutnya dapat ditambahkan fitur chat dan komen pada halaman berita dan aplikasi dapat digunakan pada sistem operasi selain android.

\section{REFERENSI}

Alviansyah, F. A., Budiman, H. A., Zaki, M., Ghifari, A., \& Amwin, A. (2018). Evaluasi Kegunaan pada Purwarupa Aplikasi Pelaporan Kerusakan Infrastruktur. 75-79.

Atthahara, H. (2018). INOVASI PELAYANAN PUBLIK BERBASIS E-GOVERNMENT : STUDI KASUS APLIKASI OGAN LOPIAN DINAS. 3(1), 66-77.

Eriyani, F. et. al. (2019). Pengembangan Aplikasi Mobile Pengaduan Masyarakat Pada Dinas Perhubungan Kota Malang Menggunakan Fitur Location Based Service Berbasis Android. Jurnal Pengembangan Teknologi Informasi dan Ilmu Komputer, 3(4), 4083-4091.

Mahdias, H. Z., Aryadita, H., \& Wicaksono, S. A. (2019). Pengembangan Aplikasi Layanan Pengaduan Masyarakat Untuk Dinas Kependudukan Dan Pencatatan Sipil Kota Pasuruan Berbasis Android. jurnal Pengembangan Teknologi Informasi dan Ilmu Komputer, 3(1), 167-176.

Mursalim, S. W. (2018). Analisis Manajemen Pengaduan Sistem Layanan Sistem Aspirasi Pengaduan Online Rakyat (LAPOR) di Kota Bandung. Jurnal Ilmu Administrasi: Media Pengembangan Ilmu dan Praktek Administrasi, 15(1), 1-17. https://doi.org/10.31113/jia.v15i1.128

Naomi, M., Noprisson, H., Komputer, F. I., Mercu, U., \& Jakarta, B. (2019). Analisa Dan Perancangan Sistem Pengaduan Mahasiswa Berbasis Web ( Studi Kasus : Universitas Mercu Buana Kranggan ) Pendahuluan Landasan Teori. JUSIBI (Jurnal Sistem Informasi Dan E-Bisnis, 1(5), 185-193.

Rio, A., \& Rina, W. (2017). Upaya Pengembangan E-Government Dalam Pelayanan Publik pada Dinas Koperasi dan UKM Kabupaten Tanggamus. Processeding KMSI, 1(09), 469-475.

Rozi, F., Listiawan, T., \& Hasyim, Y. (2017). Pengembangan Website Dan Sistem Informasi Desa Di Kabupaten Tulungagung. JIPI (Jurnal Ilmiah Penelitian dan Pembelajaran Informatika), 2(2), 107-112. https://doi.org/10.29100/jipi.v2i2.366 